\title{
Change in Southern Congressional Elections, 2004-2008
}

\author{
Charles Prysby and Katherine Watkins
}

This study examines change in southern congressional elections from 2004 to 2008 through a longitudinal analysis of district-level data. We hypothesize that change in the district congressional vote division will be influenced by: (a) change in the presidential vote in the district; and (b) change in the campaign efforts of the two parties. These are the hypotheses of central interest in this study. We also hypothesize that change in the congressional vote will be affected by: (c) the difference between the presidential and congressional vote in the district in 2004; and (d) change in the incumbency status of the two parties in the district. However, these hypotheses are of secondary interest; the variables are included primarily to make our models complete. Our findings show that change in the presidential vote had a substantial increase on the congressional vote. Change in the Democratic campaign effort also had an effect, but it was smaller than the effect of the presidential vote change. Change in the Republican campaign effort did not have a significant effect, but we urge caution in interpreting this result.

Democrats did well in the South in the 2008 elections, at least relative to recent previous election years. Barack Obama won three southern states in his successful presidential campaign, three more than the 2000 or 2004 Democratic presidential nominees, Al Gore and John Kerry, were able to carry. Democrats also did well in the 2008 congressional elections. They won two U.S. Senate seats held by Republicans while losing none of their own, a sharp contrast to 2004, when the GOP gained five Senate seats. In U.S. House elections, Democrats gained six seats, bringing their share of the southern congressional delegation to 45 percent, the highest proportion for the party since 1994. This study examines the connection between southern presidential and congressional election outcomes. Specifically, we analyze the extent to which change in the Democratic presidential vote between 2004 and 2008 translated into change in the vote for Democratic U.S. House candidates in the South.

The central research question of this study has theoretical significance beyond contributing to our understanding of what happened in the 2008 elections. If the increased vote for southern Democratic congressional candidates in 2008 was largely a result of the increase in the presidential vote for the party, then this indicates that the outcome of the 2012 congressional elections will be substantially influenced by how well Obama does in his

CHARLES PRYSBY is a professor of political science at the University of North Carolina at Greensboro. KATHERINE WATKINS is a political science major at the University of North Carolina at Greensboro who received an Undergraduate Research Assistantship Award from the university to work on this project.

The American Review of Politics, Vol. 31, Fall, 2010: 179-201

(c)2010 The American Review of Politics 
reelection effort. Should he do worse than he did in 2008, when he won about 47 percent of the southern two-party presidential vote (and about 54 percent of the national two-party vote), then Democratic congressional candidates in the South should do worse. Should he exceed his 2008 vote totals, then Democratic congressional candidates should do better. On the other hand, if the increased vote for Democratic candidates in southern House districts in 2008 was primarily due to other factors, then the outcome of future presidential elections should have less influence on the outcome of future congressional elections. Furthermore, the theoretical implications extend beyond 2012. The more general question is how much impact the presidential vote has on the congressional vote.

Much of the argument and analysis contained in this paper could be applied to another region or to the nation as a whole. We limit our analysis to the South for two reasons. First, collecting the necessary data on the 131 southern congressional districts involved substantial effort. Extending this effort to the entire country would have exceeded the time and energy that we were able to devote to this project. Second, examining the South is particularly interesting because of the questions raised about the future of the twoparty system in the region, especially in federal elections. There has been considerable speculation about whether Republicans are likely to dominate future southern presidential and congressional elections, with Democratic success limited to years when short-term forces are heavily in their favor, or whether a more generally competitive South is likely to emerge (Black and Black 1992, 344-66; Black and Black 2002, 369-404; Glaser 2005, 217-32; Lublin 2004, 217-32; Moser 2008, 9-31). We hope to contribute to an understanding of the future of party competition in the South.

\section{Change in Southern Congressional Election Outcomes}

Table 1 presents the outcomes for southern congressional elections for 1992-2008, along with the presidential vote for that time period. The 1992 election followed a reapportionment that increased the total number of southern seats in the U.S. House from 114 to 125 . While the Republicans made a net gain of ten seats, to just one for the Democrats, the Democrats remained in control of a clear majority of the seats. In 1994, however, the Republican gains were much greater, as they added sixteen new seats, giving them a narrow majority. After the 1996 election, their total increased to 71 seats, in part from three Democratic congressmen who switched between the 1994 and 1996 elections and in part from additional gains in the 1996 election. ${ }^{1}$ In both the 1998 and 2000 elections, however, the Republican failed to gain any seats, although they did add one seat between those two elections when one Democratic incumbent became an independent who caucused with 


\section{Table 1. Presidential and Congressional Election Outcomes in the South, 1992-2008}

\begin{tabular}{|c|c|c|c|c|c|}
\hline Year & $\begin{array}{c}\text { Democrat } \\
\text { Percent of } \\
\text { Presidential } \\
\text { Vote }\end{array}$ & $\begin{array}{c}\text { Democrat } \\
\text { Percent of } \\
\text { Congressional } \\
\text { Vote }\end{array}$ & $\begin{array}{l}\text { Seats } \\
\text { Dem. }\end{array}$ & $\begin{array}{l}\text { n by } \\
\text { Rep. }\end{array}$ & $\begin{array}{l}\text { Democrat } \\
\text { Seat } \\
\text { Gain/Loss }\end{array}$ \\
\hline 1992 & 49.2 & 52.0 & 77 & 48 & \\
\hline 1994 & & 43.5 & 61 & 64 & -16 \\
\hline 1996 & 50.0 & 46.2 & 54 & 71 & -7 \\
\hline 1998 & & 45.2 & 54 & 71 & 0 \\
\hline 2000 & 44.5 & 44.0 & 53 & 72 & -1 \\
\hline 2002 & & 43.2 & 55 & 76 & -1 \\
\hline 2004 & 42.4 & 40.9 & 49 & 82 & -6 \\
\hline 2006 & & 45.8 & 53 & 78 & +4 \\
\hline 2008 & 46.9 & 48.9 & 59 & 72 & +6 \\
\hline
\end{tabular}

Note: The Democratic percentages of the presidential and congressional vote are based on the twoparty vote. The Democratic seat gain or loss is based on the change in seats from the previous election outcome. In some years, some of the seat changes occurred between elections as a result of incumbents switching parties or through special elections. The total number of seats increased in 2002, so the net loss of one seat for the Democrats is based on the relative gain by each party.

Source: Data collected by the authors.

the Republicans. ${ }^{2}$ In 2002, the total number of southern seats in the U.S. House increased to 131. Both parties were able to increase their total number of seats, but the Republicans added four additional seats to two for the Democrats. We have recorded this as a net gain of one seat for the Republicans; if each party had gained three additional seats, we would have counted this as no net gain for either party. Republicans then made substantial seat gains in 2004, largely because of the second redistricting in Texas. ${ }^{3}$ Thus, the GOP gained at least one seat in each election cycle from 1992 through 2004, except for the 1997-1998 cycle, when they stayed even. If we look at the two-party vote division, a very similar pattern emerges. The Democratic share of the vote declined, with one exception: the Democrats rebounded from their 1994 vote total (only 43.5 percent of the two-party vote) to about 46 percent in 1996. The 1994 Democratic vote total was so low in part because the Democrats failed to contest 20 seats that year, compared to just seven in 1992 and nine in 1996; had they contested a comparable number in 1994, their vote share probably would have been around 46 percent. In sum, the period from 1992 through 2004 was one of continued Democratic decline and Republican growth in southern congressional elections.

Following 2004, this pattern changed abruptly. Democrats gained seats and votes in 2006, going from about 41 percent of the two-party vote in 
2004 to almost 46 percent in 2006, and making a net gain of four seats. This pattern was repeated in 2008, when Democrats captured about 49 percent of the vote and about 45 percent of the seats, their best showing in the vote since 1992 and in seats since 1996. The most obvious explanation for this Democratic surge is the shift in the national tide that took place after 2004. Decline in public approval of President Bush, combined with dissatisfaction with the Republican Party in general, led to Democratic gains nationally in the 2006 midterm elections. Continued decline in Bush's approval rating, driven largely by a lack of progress in Iraq and by a deteriorating economic situation at home, contributed greatly to another good year for Democrats in 2008, although some of the Democratic success in 2008 might be attributed to the relative effectiveness of the Obama campaign. The Democratic share of the two-party presidential vote in the South increased from 42.4 percent in 2004 to 46.9 percent in 2008. For the purposes of this paper, we do not need to determine how much of this increased Democratic presidential vote can be attributed to the unpopularity of the Bush administration, and thus might have been captured by any viable Democratic presidential candidate, and how much of it can be credited to the effectiveness of the Obama campaign, relative to the effectiveness of the McCain campaign. The key question that we ask is how much the increase in the Democratic presidential vote contributed to the increase in the Democratic congressional vote.

Another possible source for the increased Democratic success in southern congressional elections is an increased campaign effort on the part of Democrats relative to Republicans. Table 2 presents data on campaign expenditures and candidate characteristics for the 2004, 2006, and 2008 elections. Average campaign expenditures for both parties increased during this period, but considerably more so for the Democrats. In 2004, the mean Republican expenditure in a district was about $\$ 853,000$, compared to $\$ 544,000$ for the Democrats, a ratio of about 1.6. By 2008, Republican expenditure increased modestly to about $\$ 977,000$ on average, whereas Democratic spending now averaged $\$ 815,000$, yielding a ratio of only about 1.2 in favor of the Republicans. These mean scores are influenced by the high campaign expenditures made by a few candidates. For example, Deborah Honeycutt, a Republican challenger (GA 13), spent \$5.2 million in 2008 (in a losing effort), an amount far greater than what almost every other candidate spent that year. To correct for possible distortion of mean scores by a few extremely high scores, we calculated an adjusted expenditure, in which spending is capped at $\$ 3$ million. The mean adjusted campaign expenditure totals are also given in Table 2 . The patterns are very similar to those for the unadjusted expenditures, but the ratio of Republican to Democratic adjusted expenditures in 2008 is lower than the ratio of unadjusted expenditures. 


\section{Table 2. Campaign Expenditures and Candidate Characteristics for Southern U.S. House Elections, 2004-2008}

\begin{tabular}{|c|c|c|c|c|c|c|}
\hline & \multicolumn{2}{|c|}{2004} & \multicolumn{2}{|c|}{2006} & \multicolumn{2}{|c|}{2008} \\
\hline & Dem. & Rep. & Dem. & Rep. & Dem. & Rep. \\
\hline \multicolumn{7}{|l|}{$\begin{array}{l}\text { Campaign expenditure } \\
\text { (in thousands of dollars): }\end{array}$} \\
\hline Mean candidate expenditure & 544 & 853 & 613 & 1027 & 815 & 977 \\
\hline Adjusted mean expenditure & 506 & 809 & 575 & 889 & 792 & 889 \\
\hline \multicolumn{7}{|l|}{$\begin{array}{l}\text { Candidate experience } \\
\text { (number of candidates): }\end{array}$} \\
\hline Incumbent & 48 & 71 & 46 & 78 & 54 & 69 \\
\hline Experienced challenger & 8 & 18 & 12 & 8 & 8 & 10 \\
\hline Inexperienced challenger & 51 & 31 & 66 & 28 & 59 & 35 \\
\hline No candidate & 24 & 11 & 7 & 17 & 10 & 17 \\
\hline \multicolumn{7}{|c|}{$\begin{array}{l}\text { Note: Adjusted campaign expenditures are expenditures capped at } \$ 3 \text { million. Experienced chal- } \\
\text { lengers are non-incumbents who held previous elected office; inexperienced challengers are those } \\
\text { who never held elected office. } \\
\text { Source: Data compiled by the authors. }\end{array}$} \\
\hline
\end{tabular}

The relatively greater campaign effort on the part of Democratic candidates in 2008 might explain the increase in Democratic success in the congressional elections. Campaign spending is widely recognized as important by the literature on congressional elections (Ansolabehere and Gerber 1994; Green and Krasno 1988; Jacobson 1980, 1990; Kenney and McBurnett 1994; Thomas 1989). However, this factor has not been analyzed frequently in the literature on southern politics. The well-known study of the rise of southern Republicans in congressional elections by Black and Black (2002) does not look at campaign spending at all. Similarly, the studies of the growth of Republican voting in the South by Lublin (2004) and by Shafer and Johnston (2006) also do not present and analyze data on campaign spending. There are some exceptions to this general pattern. McKee (2010) presents data on campaign spending in southern congressional elections, although this is not a primary concern of his book. Prysby (2000) finds that changes in campaign spending played a role in the Republican growth in congressional elections in the 1990s. While there are strong theoretical reasons to think that change in campaign spending would affect the congressional vote, the limited investigation into this relationship for the contemporary South suggests that additional analysis is justified.

The increased Democratic success in congressional elections between 2004 and 2008 also could be the result of better Democratic candidates, 
relative to Republican candidates. Table 2 presents the number of incumbents, experienced challengers, and inexperienced challengers for each party, along with the number of districts where the party did not have a candidate on the ballot. Clearly, Democrats were at least somewhat better off in 2008 than they were in 2004 on this dimension. Their number of incumbents increased from 48 to 54, while Republicans suffered a slight decline in incumbents running for reelection. Since incumbents have the highest rate of success in congressional elections, this alone should have benefitted the Democrats (Gelman and King 1990; Jacobson 1997, 19-27; Krashinsky and Milne 1993). Similarly, Democrats may have fielded higher quality nonincumbent candidates in 2008 than in 2004, while the opposite might be true for Republicans. Candidate quality is difficult to measure, especially given the limited information that is readily available across the region, but one commonly used measure of candidate quality for non-incumbents is whether or not the individual held a previous elected office; those who had held office can be termed experienced candidates (Jacobson 1997, 34-36). The number of experienced candidates (those who held previous elected office) stayed the same for the Democrats but declined for Republicans between 2004 and 2008. Since experienced candidates tend to do better than inexperienced candidates, this should have benefitted the Democrats.

Unfortunately, whether or not a candidate is experienced is a fairly crude measure of candidate quality. More sophisticated and precise measures have been developed (Krasno and Green 1988), but it is difficult to obtain the appropriate data for all districts, especially for past elections. However, a cursory look at congressional races reveals many instances in which a high quality candidate had not previously been elected to public office, along with cases in which someone who had held such an office was not a high quality candidate. Candidate quality is a complex and somewhat subjective concept, but we might view quality as having two important dimensions: personal attractiveness and political skill (Krasno and Green 1988; Maisel et al. 1999). Personal attractiveness includes name recognition, public speaking ability, knowledge of issues, and personal integrity. Political skill involves factors directly related to running a successful campaign, such as the ability to organize a campaign staff, the ability to raise money, and the ability to obtain support from key groups. While having previously held elected office often may be a reasonable surrogate for these factors, it certainly would be possible for a political neophyte to possess many of the above characteristics, and undoubtedly a number of those elected to lowerlevel offices would not be regarded as high quality congressional candidates. Especially in the South, given the Republican philosophy and electoral base, more emphasis might have been placed by the GOP on recruiting prominent businessmen who lacked political experience but who had strong community 
connections and name recognition to run for Congress. Democrats also may have done the same thing in some places. An examination of candidate characteristics in southern congressional elections in the 1990s supports this conclusion (Prysby 2000).

For these reasons, we regard political experience as an inadequate measure of candidate quality. However, the ability to raise money is either a part of candidate quality or a factor highly related to candidate quality, depending on how we conceptualize these variables, so campaign expenditures (for which we do have good measures in this study) should be a partial measure of candidate quality (Bond et al. 1985). Therefore, when we use campaign expenditures in this study, we are measuring both candidate quality and campaign effort, and we cannot easily disentangle the two. However, for the purposes of this study, it is not necessary to do so. We do not care whether it is the spending per se or the combination of candidate quality and spending that influences the outcome of the election. In either case, these are factors that are separate from the influence of the presidential vote on the election outcome, and they are included in our analysis so that we do not incorrectly attribute increased Democrat success in congressional elections to the increased presidential vote when it truly is a result of increased campaign effort and candidate quality.

\section{Explaining Change in Southern Congressional Elections}

Based on our above discussion, we have several hypotheses about the change in the two-party vote in the congressional district, each of which is discussed below.

Hypothesis 1 (H1): Change in the congressional vote is directly affected by change in the presidential vote.

The greater the increase in the Democratic presidential vote between 2004 and 2008, the greater the increase that we would expect in the Democratic congressional vote, other factors being equal. The logic here is quite straightforward. First, there is the presidential coattails effect. Voters who were attracted to vote for Obama might want also to vote for a Democratic congressional candidate, who undoubtedly would be more likely to support Obama's presidential initiatives than would the Republican candidate. The same argument applies to McCain voters. Second, an increased vote for the Democratic presidential candidate also indicates a shift in a Democratic direction of short-term forces operating that year, including such important factors as the approval of the incumbent president. These short-term forces may have led to more support for Democratic congressional candidates apart 
from any direct coattail effects. A similar argument applies to districts where the Republican presidential vote increased from 2004 to 2008. Third, an increased Democratic presidential vote could indicate an increase in the Democratic campaign effort, produced either by the Obama campaign itself or working in combination with state parties. Fourth, change in the presidential vote may indicate a shift in the underlying partisanship of the district, which could occur because of changes in the composition of the district electorate through migration or generational replacement or through shifts in individual partisan loyalties. The underlying partisanship of the district also could be altered by changes in the district boundaries, which occurred in a small number of districts. For most districts, we would anticipate that shifts in underlying partisanship over a four-year period would be small, but changes in short-term forces might well be large.

Hypothesis 2 (H2): Change in the congressional vote is related to the difference between the presidential vote and the congressional vote in 2004.

The more that the Democratic presidential vote exceeded the Democratic congressional vote in 2004 , the greater the increase that we would expect in the Democratic congressional vote between 2004 and 2008, other factors being equal. Conversely, the more that the Democratic congressional vote exceeded the Democratic presidential vote in 2004, the greater the decrease that we would expect in the Democratic congressional vote, other factors being equal. Districts where the Democratic congressional candidate ran far behind the presidential ticket should have been perceived as districts where there was great potential for increase, leading to a stronger Democratic campaign effort in 2008 (and in 2006, for that matter) and possibly to Republicans failing to defend the seats as vigorously as possible, especially if the incumbent was not running for reelection. If this is so, then the strategic behavior of candidates would produce greater Democratic increases in seats where the Democratic congressional vote previously lagged far behind the presidential vote (Jacobson 1989; Jacobson and Kernell 1981). We at least partially control for this indirect effect by including campaign expenditures in our model, but since expenditures do not fully capture all dimensions of campaign effort, some of this indirect effect could remain. Comparable arguments can be made for districts where the Republican congressional candidate ran well behind the Republican presidential candidate in 2004. These districts represented the best opportunities for Republicans to increase their share of the vote. This hypothesis is not of central theoretical interest in this study, but we include it for control purposes. 


\section{Hypothesis 3 (H3): Change in the congressional vote is affected} by change in the campaign efforts of the two parties.

The greater the increase in Democratic campaign spending between 2004 and 2008, the greater the increase in the Democratic congressional vote, everything else being equal. Similarly, the greater the increase in Republican campaign spending between 2004 and 2008, the greater the increase in the Republican congressional vote, everything else being equal. We use campaign spending to measure campaign effort because these data are the best that we have. Of course, campaign expenditures do not capture all dimensions of campaign effort. Some candidates may spend their campaign funds more efficiently. Other candidates may benefit from substantial volunteer efforts or from spending by independent groups on their behalf. A high quality candidate - one who is well known and highly respected in the district, for example - should do better than a candidate who lacks such quality, even if their campaign expenditures are equal. As we also noted earlier, campaign spending is at least an indirect measure of candidate quality, a point that we need to keep in mind in the following analysis.

Hypothesis 4 (H4): Change in the congressional vote is affected by change in the incumbency status of the seat.

When either party loses the advantage of incumbency between 2004 and 2008, its share of the vote should decline, everything else being equal. Similarly, a gain of incumbency (i.e., not having an incumbent candidate in 2004 but having one in 2008) should produce an increase in the congressional vote for the party. This hypothesis is not of central theoretical interest in this study, but we include it for control purposes.

\section{Hypothesis 5 (H5): Change in congressional campaign spending} is affected by the change in the presidential vote.

Districts where the Democratic presidential vote increased the most between 2004 and 2008 should be the ones where Democratic campaign spending increased the most and Republican spending the least. Conversely, districts where the Democratic presidential vote increased little or not at all should be the ones where Democratic campaign spending increased the least and Republican spending the most. The logic behind this hypothesis is that change in the presidential vote indicates change in the short-term forces that affect elections, and where these forces shift strongly in a Democratic direction, they encourage a stronger campaign effort by Democratic congressional candidates and discourage a strong effort by Republican candidates. 
This hypothesis is consistent with the more general argument made by Jacobson and Kernell (1981), which is that potential candidates and their supporters make decisions well in advance of the election, based on their estimate of future political conditions.

Hypothesis 6 (H6): Change in congressional campaign spending is affected by the difference in the presidential and congressional vote for the party and by change in the incumbency status of the two parties.

Districts where the congressional candidate ran behind the presidential candidate of the party in 2004 are districts with more potential for improvement in the congressional vote, so they should be more likely to receive an increase in campaign spending, other factors being equal. Converse arguments apply to districts where the congressional candidate ran behind the presidential candidate of the party. Because incumbents generally are able to raise more money, change in the incumbency status of the district also should affect change in campaign spending. Gaining an incumbent (i.e., going from not having an incumbent candidate in 2004 to having one in 2008) should result in increased spending, everything else being equal. Losing an incumbent should have the opposite effect. These expectations also are consistent with the strategic politician's argument advanced by Jacobson and Kernell (1981).

The hypotheses that are of major theoretical interest in this study are $\mathrm{H} 1$ and H3. They indicate two different sources of change in congressional election outcomes. Both hypotheses can be true, but we are interested in the relative impact of each variable. Was the increase in the Democratic congressional vote between 2004 and 2008 due more to change in the presidential vote or more to change in campaign effort? We also want to consider the possible effect of change in the presidential vote on change in campaign effort, which is indicated by hypothesis $\mathrm{H} 5$. Change in the presidential vote may have both direct and indirect effects on the congressional vote, so it is important to examine both. The other hypotheses (H2, H4, and H6) are included primarily to make sure that appropriate controls are present in the analysis.

\section{Data and Methods}

This study analyzes data on southern congressional elections from 2004 to 2008 by using data on each congressional seat over time and by focusing on the sources of change in district election outcomes. The South is defined here as the eleven states of the old Confederacy. This district-level 
longitudinal analysis has particular advantages over the more typical crosssectional analysis of congressional districts. With our method, we are better able to directly relate change in the electoral outcomes of congressional elections to specified district-level causal factors. In particular, we analyze the extent to which change in the presidential vote in the district produced change in the congressional vote in the district. With a cross-sectional analysis, one would correlate the level of the Democratic (or Republican) vote with the level of the Democratic (or Republican) congressional vote. That correlation naturally might result from a variety of other district characteristics, which would have to be included in the model to ensure that the coefficients are not inflated through the effects of confounding variables. While the effects of confounding variables are not eliminated by our method, they are greatly mitigated. Moreover, our method comes closer to capturing how people think about the effect of the presidential vote on the congressional vote, which is to speculate on how much a congressional candidate is advantaged if his or her party's presidential candidate does better than in past elections.

One problem with a longitudinal analysis of congressional districts is any redistricting that occurs during the time period under investigation. Change in the district boundaries introduces a confounding variable into the analysis; the greater the change in the boundaries, the more serious the problem. This problem is largely avoided in this study because we focus on change between 2004 and 2008. Most of the redistricting in the South in this decade occurred before the 2004 election. Nine states established their district boundaries prior to the 2002 election and retained them throughout the decade. Texas engaged in a second round of redistricting, which was completed prior to the 2004 election. Unfortunately, some redistricting took place after 2004. Texas was forced by a court decision to redraw the lines of five districts after 2004, and the Georgia legislature, perhaps stimulated by the success that Texas Republicans had in redrawing lines for 2004, decided to do the same for Georgia in 2005. Thus, eighteen districts were redrawn after 2004; in some cases, the change in the district was substantial. However, only about 14 percent of the districts in the South had boundary changes after 2004, and our method does help to control for this problem, as we shall explain shortly, so this complication is unlikely to have significantly affected our results.

Louisiana presents special problems, owing to its unusual electoral system. Beginning in 1978, Louisiana congressional elections were held under an "open primary" arrangement, in which candidates from all parties participated. This system continued through 2006 for congressional elections, and it remains in effect for state elections. In this system, any candidate receiving over 50 percent of the vote is elected. If no candidate receives 
an absolute majority, the top two candidates (regardless of partisan affiliation) are entered in the runoff election. While Louisiana uses the terms primary and runoff, these are misnomers. The "open primary" is in fact a general election, since candidates can be - and in fact often are - elected at this time. The system is more accurately described as a two-stage general election. In calculating the Republican and Democratic percentages of the congressional vote in 2004, it makes more sense to do this is terms of the vote for all Republican and Democratic candidates in the open primary for cases where the open primary was decisive or where the runoff election was between two candidates of the same party. ${ }^{4}$ In 2008, Louisiana switched its congressional elections to the partisan general election method used in other states, so the vote percentages for that year are calculated in the typical fashion.

Our analysis of the effect of the presidential vote on the congressional vote relies on a straightforward regression analysis, the details of which are explained below. Both presidential and congressional vote totals are measured as the Democratic percentage of the two-party vote. We focus on the Democratic vote percentage simply because the Democrats gained votes and seats between 2004 and 2008. Obviously, exactly the same conclusions would result if we used the Republican percentage of the two-party vote. Our cases are the 131 southern congressional districts. Our analysis attempts to explain change in the district congressional vote in terms of changes in the presidential vote, campaign effort, and incumbency status in the district. In order to improve the accuracy of the analysis, we adjust the congressional vote and the campaign spending figures.

We adjust the congressional vote to correct for one obvious source of change in the vote: whether or not the seat is contested by both parties in both years. For example, if Democrats failed to contest a particular seat in 2004, but fielded a candidate in 2008, their vote share would increase substantially. Even a weak and poorly funded candidate running in a district dominated by the other party usually will be able to win at least 20 percent of the vote, which would be a substantial increase over zero percent. Our solution to the above problem is to adjust the two-party congressional vote so that it falls between 20 and 80 percent, on the grounds that this is the effective range when seats are contested, even if one of the candidates puts forth only a minimal campaign effort. In essence, the adjusted vote represents an estimate of what the congressional vote would have been if both parties ran a candidate in every district. If anything, this appears to be a conservative estimate, but this adjustment at least substantially corrects for change in the congressional vote that is produced simply by change in the competitive status of the district. ${ }^{5}$ 
In some years, very high campaign expenditures by a few candidates have the potential to significantly affect the analysis. Such high expenditures can be misleading because the marginal impact of additional dollars undoubtedly drops off greatly at high expenditure levels. For example, if a party increases its expenditure in a congressional district from $\$ 400,000$ in one year to $\$ 900,000$ in the following election year, that $\$ 500,000$ increase represents a substantially greater campaign effort. But if the increase in another district is from $\$ 800,000$ to $\$ 5,800,000$ - an increase of $\$ 5$ millionwe probably would not argue that this second increase in campaign effort is truly ten times greater than the first increase. Based on this reasoning, we use adjusted campaign spending figures in our analysis in order to diminish distortions that might be caused by very atypical cases. As discussed earlier, the adjusted campaign spending caps expenditures at $\$ 3$ million, on the grounds that expenditures in excess of this amount have greatly decreased marginal utility per dollar spent.

\section{Data Analysis and Interpretation}

Table 3 presents descriptive statistics for the variables used in the analysis. As we can see, the mean increase in the Democratic share of the adjusted two-party congressional vote between 2004 and 2008 was 5.74 percent. Table 1 shows that in the South as a whole, there was an 8 point increase in the Democratic share of the two-party congressional vote between 2004 and 2008, much larger than the mean increase in the district adjusted vote. This difference results from: (a) the adjustment in the two-party vote, which truncates the vote to run from 20 to 80 percent; and (b) the difference between the mean Democratic vote for districts and the overall share of the vote, a difference that is produced by variation in turnout across districts.

This variable has considerable variation, as the range and standard deviation indicate. Some of the cases where there was a large change in the vote division were seats that were redistricted; others were ones that were uncontested in one year and not only contested but competitive in the other year. For example, Tom Feeney (R-FL 24) was unopposed in 2004, but in 2008 he faced a well-financed Democratic opponent, Suzanne Kosmos, who won with 58 percent of the vote, due in part to some well-publicized ethical problems that Feeney had. This produced a 38 point increase in the Democratic share of the adjusted congressional vote. Some cases with large vote changes involved districts that were contested in both of the years. For example, William Jefferson (D-LA 5) defeated his Republican opponent overwhelmingly in 2004, but lost to Joseph Cao in 2008, with ethical problems of the incumbent a major factor in this race as well. This produced a 30 point decrease in the Democratic share of the adjusted congressional vote. 
Table 3. Descriptive Statistics for Variables used in Table 4

\begin{tabular}{|c|c|c|c|}
\hline & $\begin{array}{l}\text { Mean Score } \\
\text { (S.D.) }\end{array}$ & Min. & Max. \\
\hline $\begin{array}{l}\text { Change in adjusted Democratic congressional } \\
\text { vote, } 2004-2008\end{array}$ & $\begin{array}{c}5.74 \\
(11.72)\end{array}$ & -30.40 & 38.25 \\
\hline $\begin{array}{l}\text { Change in Democratic presidential vote, } \\
2004-2008\end{array}$ & $\begin{array}{l}3.76 \\
(4.85)\end{array}$ & -11.11 & 16.52 \\
\hline $\begin{array}{l}\text { Difference between Democratic presidential } \\
\text { and adjusted congressional vote, } 2004\end{array}$ & $\begin{array}{c}-.74 \\
(13.27)\end{array}$ & -33.94 & 25.00 \\
\hline Gain of incumbent by Democrats, 2004-2008 & $\begin{array}{l}.08 \\
(.28)\end{array}$ & 0 & 1 \\
\hline Loss of incumbent by Democrats, 2004-2008 & $\begin{array}{c}.04 \\
(.19)\end{array}$ & 0 & 1 \\
\hline Gain of incumbent by Republicans, 2004-2008 & $\begin{array}{l}.10 \\
(.30)\end{array}$ & 0 & 1 \\
\hline Loss of incumbent by Republicans, 2004-2008 & $\begin{array}{l}.11 \\
(.32)\end{array}$ & 0 & 1 \\
\hline $\begin{array}{l}\text { Change in adjusted Democratic campaign } \\
\text { expenditure, 2004-2008 }(\mathrm{N}=128)\end{array}$ & $\begin{array}{l}2.93 \\
(9.83)\end{array}$ & -28.90 & 30.00 \\
\hline $\begin{array}{l}\text { Change in adjusted Republican campaign } \\
\text { expenditure, 2004-2008 }(\mathrm{N}=129)\end{array}$ & $\begin{array}{c}.84 \\
(8.32)\end{array}$ & -24.54 & 30.00 \\
\hline \multicolumn{4}{|c|}{$\begin{array}{l}\text { Note: Entries are mean scores for the southern congressional districts. Standard deviations are } \\
\text { parentheses. See the text for details on the variables. The number of districts is } 131 \text {, except for th } \\
\text { campaign spending variables, where the correct } \mathrm{N} \text { is given. Adjusted campaign expenditures ar } \\
\text { measured in units of } \$ 100,000 \text {. } \\
\text { Source: Data collected by the authors. }\end{array}$} \\
\hline
\end{tabular}

These examples illustrate the fact that there are a variety of factors that are specific to individual districts that can play a major role in congressional elections.

Change in the Democratic share of the two-party presidential vote was somewhat smaller than change in the congressional vote. The mean Democratic increase was 3.76 percentage points, about two full points less than the change in the congressional vote; there is substantial variation in this variable as well, but not as much as in the congressional vote. This makes theoretical sense, since many of the idiosyncratic factors that produce large changes in congressional outcomes are not present in the presidential 
contest. In fact, were it not for the redistricting that took place in Georgia and Texas after 2004, there would be even less variation in this variable.

There were larger increases in Democratic adjusted campaign expenditures than in Republican expenditures: an average increase of almost $\$ 300,000$ for Democratic candidates between 2004 and 2008, compared to just $\$ 84,000$ more for Republican candidates. This is what we would expect, given that 2008 was a more encouraging year for Democrats. Jacobson $(1980,1990)$ suggests that expenditures by challengers are more important than expenditures by incumbents, but others argue that the effort of the incumbent should be considered as well (Green and Krasno 1988, 1990; Kenney and McBurnett 1994; Thomas 1989). We therefore included changes in the campaign expenditures of both parties in the following analysis without distinguishing between whether it was incumbent or challenger spending. Perhaps a more careful analysis of spending might find differences along these lines.

Similar patterns are present in changes in incumbency status, where the mean scores indicate the proportion of districts with the change. There were twice as many districts where the Democrats gained incumbency status as ones where they lost that status, a difference that is partly due to seats gained by Democrats in 2006 and partly due to few Democratic retirements in 2008. For Republicans, there were as many districts where they lost incumbency status as ones where they gained that status.

To test our hypotheses, we ran multiple regression analyses of the change in the Democratic share of the two-party congressional vote, using the independent variables described in Table 3. Table 4 presents the results of two analyses: Model 1 excludes the campaign expenditure variables, while Model 2 includes them. In the first analysis, there is a clear relationship between the change in the presidential vote and change in the congressional vote. Each one point increase in the Democratic share of the presidential vote is associated with an increase of slightly less than one-half of one point in the Democratic share of the congressional vote. Change in the congressional vote is also significantly related to the difference between the presidential vote and the congressional vote in 2004, as we predicted. However, the four variables that measure change in incumbency status do not all have the effects that we predicted. Both variables that measure a loss of incumbency are significantly related to change in the congressional vote in the direction that we would expect, but there seems to be little effect for a gain in incumbency status for either party. Since these variables are included largely for control purposes, we have not attempted further analysis to determine why some of the relationships are not as we predicted. However, we can speculate on some possibilities. First, the number of cases where incumbency changed is small, so atypical patterns in a handful of cases might 
Table 4. Regression Analysis of Congressional Vote Change, 2004-2008

\begin{tabular}{|c|c|c|}
\hline & Model 1 & Model 2 \\
\hline $\begin{array}{l}\text { Change in Democratic presidential vote, } \\
2004-2008\end{array}$ & $\begin{array}{l}.451^{* *} \\
(.168)\end{array}$ & $\begin{array}{l}.449 * * \\
(.167)\end{array}$ \\
\hline $\begin{array}{l}\text { Difference between Democratic presidential } \\
\text { and congressional vote, } 2004\end{array}$ & $\begin{array}{l}.330^{* *} \\
(.063)\end{array}$ & $\begin{array}{l}.329 * * \\
(.068)\end{array}$ \\
\hline Gain of incumbent by Democrats, 2004-2008 & $\begin{array}{l}4.176 \\
(3.572)\end{array}$ & $\begin{array}{c}1.344 \\
(3.779)\end{array}$ \\
\hline Loss of incumbent by Democrats, 2004-2008 & $\begin{array}{l}-16.601 * * \\
(4.384)\end{array}$ & $\begin{array}{l}-12.167 * * \\
(4.588)\end{array}$ \\
\hline Gain of incumbent by Republicans, 2004-2008 & $\begin{array}{c}-.155 \\
(2.786)\end{array}$ & $\begin{array}{l}-1.276 \\
(2.861)\end{array}$ \\
\hline Loss of incumbent by Republicans, 2004-2008 & $\begin{array}{c}7.654^{*} \\
(3.200)\end{array}$ & $\begin{array}{c}3.869 \\
(3.350)\end{array}$ \\
\hline $\begin{array}{l}\text { Change in Democratic campaign expenditure, } \\
2004-2008\end{array}$ & $\begin{array}{l}.268^{*} \\
(.114)\end{array}$ & \\
\hline $\begin{array}{l}\text { Change in Republican campaign expenditure, } \\
\text { 2004-2008 }\end{array}$ & $\begin{array}{l}-.075 \\
(.134)\end{array}$ & \\
\hline Adjusted $\mathrm{R}^{2}$ & .385 & .418 \\
\hline$(\mathrm{N})$ & $(131)$ & $(126)$ \\
\hline \multicolumn{3}{|c|}{$\begin{array}{l}* * \mathrm{p}<.01, * \mathrm{p}<.05 \text { (two-tailed tests) } \\
\text { Note: Entries are unstandardized regression coefficients, with standard errors in parentheses. The } \\
\text { dependent variable is the change in the Democratic percentage of the congressional vote in the dis- } \\
\text { trict from } 2004 \text { to } 2008 \text {. Vote percentages are measured as percentages of the two-party vote, and the } \\
\text { congressional vote is adjusted as explained earlier. Change in the campaign expenditure is measured } \\
\text { in hundreds of thousands of dollars and is adjusted as explained earlier. The loss or gain of incum- } \\
\text { bent by either party measures whether there was a change in the incumbency situation of a seat } \\
\text { between } 2004 \text { and } 2008 \text {. See the text for details on these variables. } \\
\text { Source: Data collected by the authors. }\end{array}$} \\
\hline
\end{tabular}

distort the relationships. Second, there is a relationship between one party losing the advantage of incumbency and the other party gaining it. For example, in about one-half of the seats where Republicans lost their incumbency advantage, Democrats gained it. It may be that the coefficient for the Republican loss is capturing some of the effect of the Democratic gain. ${ }^{6}$ The same may be true for the combination of variables representing a Democratic loss and a Republican gain. 
Model 2 includes campaign spending change variables. One of these variables, the change in the Democratic campaign expenditure, has a significant effect. The regression coefficient indicates that each additional expenditure of $\$ 100,000$ produces slightly over an additional one-quarter of a percentage point in the vote, with other factors held constant. An increase in spending of $\$ 300,000$, which is the average increase for Democratic candidates between 2004 and 2008, would yield a predicted increase in the vote of about 0.8 percentage points. However, change in the Republican campaign expenditure has little effect on the vote. This does not make theoretical sense; it is extremely hard to believe that Republican candidates would have done just as well if they had spent less. The lack of a significant relationship for this variable could be due to large increases in spending by Republican incumbents who were in danger of losing their seats. As Jacobson (1980) has suggested, sometimes high incumbent spending appears to have little effect on the vote because it occurs in situations where incumbents are seriously threatened.

An examination of the cases where Republican spending changed the most between 2004 and 2008 suggests that the lack of a significant effect for Republican spending change is at least partially a result of the influence of outlying cases. For example, there were two Florida districts (districts 21 and 25), both held by Republican Cuban Americans, in which the incumbents did not face a Democratic opponent in 2004 but received a serious challenge in 2008. In both cases, their adjusted spending increased by over $\$ 2$ million, but their adjusted share of the vote declined by over 20 points. A third Republican Cuban American in the Miami area upped her spending by about $\$ 2$ million in response to a more serious Democratic challenge, yet captured less of the vote in 2008 than in 2004. In North Carolina, the incumbent Republican in district 8 increased his spending by well over $\$ 1$ million, yet saw his share of the vote decline by about 10 percentage points, which resulted in his defeat. The outcomes for a few seats held by Democrats also may have contributed to the weak overall relationship between Republican spending change and vote change. For example, the incumbent Democrat in Texas 17 faced a strong Republican opponent in 2004, but received only a minimal challenge in 2008; even though Republican spending declined by \$2.5 million between 2004 and 2008, the Republican share of the vote changed very little. These few cases where the Republican campaign spending changed greatly without producing a commensurate change in vote may help to explain why our regression analysis does not find a statistically significant effect for change in Republican spending but does for Democratic spending.

The effect of the change in the Democratic presidential vote on change in the congressional vote is unaffected by including the spending variables, 
which indicates that this effect does not operate through effects on campaign spending. On the other hand, the coefficients for three of the four incumbency status change variables decrease substantially, indicating that a good portion of the incumbency effects operate through effects on campaign spending, which is what we would expect.

These results indicate that the improvement in the Democratic presidential vote between 2004 and 2008 had a substantial impact on the congressional vote. The average increase in the Democratic share of the twopart vote was about 3.76 percentage points. When this is multiplied by the regression coefficient for the variable (about 0.45 ), we get a predicted increase of about 1.7 percentage points in the congressional vote. This is about twice the increase that is predicted from the average increase in campaign spending by Democratic candidates, which is calculated above to be 0.8 percentage points. This indicates that the Obama impact was largely a direct effect on the vote, rather than an effect on the strategic decisions of candidates and their supporters. Even if Democrats had not increased their spending relative to Republicans, it appears that they would have won a larger share of the congressional vote. Furthermore, the campaign spending variables capture aspects of candidate quality, not just simple spending, so the impact of the Obama vote is separate from any effects of increased candidate quality as well. We should note, however, that our regression analysis predicts only about 40 percent of the variation in the congressional vote change, which indicates that there are many factors that affect congressional election outcomes that are not captured by the variables that we use in our analysis.

Finally, we examine some factors that might affect change in campaign spending. The results of regression analyses of change in Democratic and Republican campaign spending between 2004 and 2008 are presented in Table 5. Change in the Democratic presidential vote has little effect, as we already have suggested. This analysis fails to support our fifth hypothesis, which specified that change in the presidential vote would be related to change in campaign effort. Perhaps on a regional basis, or at the state level, Democrats were encouraged to contribute more money because it appeared to be a good year for Democratic candidates, but this relationship does not hold true at the district level. Districts where the Democratic presidential vote increased substantially did not see greater increases in the Democratic campaign effort than did districts where the Democratic presidential vote did not increase substantially. On the other hand, the difference between the presidential and congressional vote does have a significant effect, as we predicted. Districts where there appeared to be greater potential for increasing a party's vote attracted significantly more money for the party than other districts. The incumbency variables have mixed effects, some significant and some not. Since incumbency effects are not a concern of this study, we have 
Table 5. Regression Analysis of Congressional Vote Change, 2004-2008

\begin{tabular}{|c|c|c|}
\hline & $\begin{array}{l}\text { Democratic } \\
\text { Spending }\end{array}$ & $\begin{array}{l}\text { Republican } \\
\text { Spending }\end{array}$ \\
\hline $\begin{array}{l}\text { Change in Democratic presidential vote, } \\
2004-2008\end{array}$ & $\begin{array}{l}.135 \\
(.153)\end{array}$ & $\begin{array}{l}.205 \\
(.130)\end{array}$ \\
\hline $\begin{array}{l}\text { Difference between Democratic presidential } \\
\text { and congressional vote, } 2004\end{array}$ & $\begin{array}{l}.122 * \\
(.058)\end{array}$ & $\begin{array}{l}.211^{* *} \\
(.050)\end{array}$ \\
\hline Gain of incumbent by Democrats, 2004-2008 & $\begin{array}{c}2.103 \\
(3.279)\end{array}$ & $\begin{array}{l}-9.564 * * \\
(2.748)\end{array}$ \\
\hline Loss of incumbent by Democrats, 2004-2008 & $\begin{array}{c}-17.267 * * \\
(3.250)\end{array}$ & $\begin{array}{l}-5.495 \\
(3.372)\end{array}$ \\
\hline Gain of incumbent by Republicans, 2004-2008 & $\begin{array}{c}.683 \\
(2.512)\end{array}$ & $\begin{array}{l}-6.529 * * \\
(2.148)\end{array}$ \\
\hline Loss of incumbent by Republicans, 2004-2008 & $\begin{array}{c}9.380 \\
(2.900)\end{array}$ & $\begin{array}{c}1.914 \\
(2.469)\end{array}$ \\
\hline Adjusted $\mathrm{R}^{2}$ & .290 & .278 \\
\hline$(\mathrm{N})$ & $(128)$ & $(129)$ \\
\hline \multicolumn{3}{|c|}{$\begin{array}{l}* * \mathrm{p}<.01, * \mathrm{p}<.05 \text { (two-tailed tests) } \\
\text { Note: Entries are unstandardized regression coefficients, with standard errors in parentheses. The } \\
\text { dependent variable is the change in the Democratic percentage of the congressional vote in the dis- } \\
\text { trict from } 2004 \text { to } 2008 \text {. Vote percentages are measured as percentages of the two-party vote, and the } \\
\text { congressional vote is adjusted as explained earlier. Change in the campaign expenditure is measured } \\
\text { in hundreds of thousands of dollars and is adjusted as explained earlier. The loss or gain of incum- } \\
\text { bent by either party measures whether there was a change in the incumbency situation of a seat } \\
\text { between } 2004 \text { and } 2008 \text {. See the text for details on these variables. } \\
\text { Source: Data collected by the authors. }\end{array}$} \\
\hline
\end{tabular}

not attempted to explain these mixed and inconsistent results, but the points made in our discussion of incumbency effects on the vote may apply here as well.

\section{Conclusion}

This study finds that the change in the outcomes of southern congressional election between 2004 and 2008 was a result of both change in the presidential vote and change in campaign effort, with the change in the presidential vote having an impact that was about twice as great as the change in campaign effort. The effect of the presidential vote could represent the combination of several related factors: the diminished popularity of 
the Bush administration in particular and the Republican Party in general; the unusually strong campaign organization that Obama established in some southern states; and the personal appeal of the Democratic ticket relative to the Republican ticket. We have not attempted to disentangle these related factors. Regardless of the specific reasons why the Democratic presidential vote increased, our analysis suggests that the results of the 2012 congressional elections will be substantially affected by the outcome of the presidential election. If Obama is reelected with a larger share of the vote than he obtained in the South in 2008, Democrats would likely gain an even greater share of the congressional vote, which most likely would yield additional seats. If Obama wins a significantly smaller share of the vote in 2012, Democrats are likely to win a smaller share of the congressional vote and capture fewer seats. More generally, Democratic success in southern congressional elections seems dependent on success in presidential elections.

The results of this study also indicate that changes in campaign effort have an impact on the congressional vote, and these effects are independent of the effect of change in the presidential vote. Thus, the effects of the change in the presidential vote on the congressional vote can be accentuated or mitigated by the campaign efforts of the two parties. In 2008, the effect of the Obama vote was heightened by increased campaign effort of Democratic congressional candidates, relative to that of the Republicans. If there had not been this change in campaign effort, Democratic gains would have been smaller. The 2012 congressional elections should be influenced by the campaign efforts of the two parties, but these data suggest that this influence will be weaker than the influence of the presidential vote. Of course, the impact of campaign effort depends on the magnitude of the change in this variable. In 2008, the Democratic campaign expenditure increased on average over $\$ 200,000$ more than the Republican expenditure did, and this increase produced an increase in the Democratic congressional vote that was about onehalf of the increase produced by the greater Democratic presidential vote. However, our data indicate that if the Democratic spending increase had been greater - say $\$ 500,000$ more per district - then the increased campaign effort would have generated as much impact as the increased presidential vote.

We normally think of the two above factors as moving together. In good years for the presidential candidate, the party finds it easier to recruit good candidates and to raise money (Jacobson and Kernell 1981). However, these data indicate that this relationship does not exist at the district level. Democrats raised considerably more money in 2008 than in 2004, and their ability to do so undoubtedly was influenced by the fact that it was a good year for Democrats, but changes in campaign spending at the district level were unrelated to changes in the presidential vote. This suggests that greater 
campaign effort, if it could be generated in an unfavorable year, would be beneficial. Another interesting finding is that increased spending by Republicans had little effect on the vote. As we have suggested, caution is warranted in interpreting this finding, but it may be that in a year when shortterm forces are working against a party, increased campaign effort does not yield the payoff that it does when short-term forces are favorable to the party, a conclusion that is contradictory to the one immediately above.

Given the limited study of the effects of campaign effort in southern congressional elections, we suggest that further research in this area is desirable. There are a number of aspects of campaign spending that this study did not have the time and space to analyze, including: (a) the difference in the impact of challenger and incumbent spending; (b) differences in the effect of how campaign funds are spent ${ }^{7}$; and (c) differences in the effect of spending by party depending on the direction of short-term political forces in the election year. Additionally, candidate quality has not been adequately studied, yet there is every reason to think that this is an important factor. A better understanding of these understudied topics will contribute to our knowledge of southern politics.

\section{NOTES}

${ }^{1}$ The three Democrats who switched parties and became Republicans following the 1994 election were: Tauzin (LA 3), Deal (GA 9), and Parker (MS 4). A fourth Democrat, Greg Laughlin (TX 14), also switched, but he was defeated in the 1996 primary and thus was not a candidate in the 1996 general election.

${ }^{2}$ Virgil Goode (VA 5) became an independent and joined the Republican caucus in January, 2000.

${ }^{3}$ Following the 2002 elections, Republicans held 15 of the 32 Texas seats. After the 2004 elections, they held 21 of the 32 seats.

${ }^{4}$ For example, consider LA 6 in 2004. The incumbent Republican faced two Democratic challengers in the open primary. The incumbent was reelected with $73 \%$ of the vote. The two Republicans combined to capture $27 \%$ of the vote. We would consider these two percentages to be the two-party vote division. Another example is LA 2 in 2006. Five major-party candidates, four Democrats and one Republican, competed in the open primary. No one won a majority of the vote, so the top two vote winners, both Democrats, ran in the general election. In such a case, we would count the Democratic vote as the combined percent for the four Democrats in the open primary and the Republican vote as the percent for the one Republican in the open primary.

${ }^{5}$ There was a substantial decline between 2004 and 2008 in the number of districts where the Democrats failed to run a candidate, from 24 in 2004 to 11 in 2008 . There also was an increase in seats uncontested by Republicans, which went from 11 in 2004 to 17 in 2008.

${ }^{6}$ This is not a case of true multicolinearity, as the correlation between these two variables is only about .60 , but given the small number of cases involved, it is possible that a similar effect is occurring. 
${ }^{7}$ For example, Ansolabehere and Gerber (1994) argue that campaign spending on communications or voter contact is a better measure of campaign intensity than total spending.

\section{REFERENCES}

Ansolabehere, Stephen, and Alan Gerber. 1994. The Mismeasure of Campaign Spending: Evidence from the 1990 U.S. House Elections. Journal of Politics 56:1106-1118.

Black, Earl, and Merle Black. 2002. The Rise of Southern Republicans. Cambridge, MA: Harvard University Press.

Black, Earl, and Merle Black. 1992. The Vital South. Cambridge, MA: Harvard University Press.

Bond, Jon, Cary Covington, and Richard Fleisher. 1985. Explaining Challenger Quality in Congressional Elections. Journal of Politics 47:510-529.

Gelman, Andrew, and Gary King. 1990. Measuring Incumbency Without Bias. American Journal of Political Science 34:1142-1164.

Glaser, James M. 2005. The Hand of the Past in Contemporary Southern Politics. New Haven, CT: Yale University Press.

Green, Donald, and Jonathon Krasno. 1988. Salvation for the Spendthrift Incumbent: Reestimating the Effects of Campaign Spending in House Elections. American Journal of Political Science 32:884-907.

Green, Donald, and Jonathon Krasno. 1990. Rebuttal to Jacobson's 'New Evidence for Old Arguments.' American Journal of Political Science 34:363-372.

Jacobson, Gary. 1980. Money in Congressional Election. New Haven, CT: Yale University Press.

Jacobson, Gary. 1989. Strategic Politicians and the Dynamics of U.S. House Elections. American Political Science Review 83:773-794.

Jacobson, Gary. 1990. The Effects of Campaign Spending in House Elections: New Evidence for Old Arguments. American Journal of Political Science 34:334-362.

Jacobson, Gary. 1997. The Politics of Congressional Elections, 4th ed. New York: Longman.

Jacobson, Gary, and Samuel Kernell. 1981. Strategy and Choice in Congressional Elections. New Haven, CT: Yale University Press.

Kenney, Christopher, and Michael McBurnett. 1994. An Individual-level Multiequation Model of Expenditure Effects in Contested House Elections. American Political Science Review 88:699-707.

Krashinsky, Michael, and William Milne. 1993. The Effects of Incumbency in U.S. Congressional Elections, 1950-1988. Legislative Studies Quarterly 18:321-344.

Krasno, Jonathon, and Donald Green. 1988. Preempting Quality Challengers in House Elections. Journal of Politics 50:920-936.

Lublin, David. 2004. The Republican South. Princeton, NJ: Princeton University Press.

Maisel, L. Sandy, Walter Stone, and Cherie Maestas. 1999. Reassessing the Definition of Quality Candidates. Paper presented at the Midwest Political Science Association Meeting.

McKee, Seth. 2010. Republican Ascendancy in Southern U.S. House Elections. Boulder, CO: Westview Press.

Moser, Bob. 2008. Blue Dixie. New York: Henry Holt. 
Prysby, Charles. 2000. Southern Congressional Elections in the 1990s: The Dynamics of Change. American Review of Politics 21:155-178.

Shafer, Byron E., and Richard Johnston. 2006. The End of Southern Exceptionalism. Cambridge, MA: Harvard University Press.

Thomas, Scott. 1989. Do Incumbent Expenditures Matter? Journal of Politics 51:965976. 